Article

\title{
Niche Theory Analysis of Sustainable Strategic Relationships among MICE Destinations: A Case of Four Cities in Waikato and Bay of Plenty Regions of New Zealand
}

\author{
Jiwon Lee ${ }^{(D)}$
}

Citation: Lee, J. Niche Theory Analysis of Sustainable Strategic Relationships among MICE Destinations: A Case of Four Cities in Waikato and Bay of Plenty Regions of New Zealand. Tour. Hosp. 2022, 3 , 137-152. https://doi.org/10.3390/ tourhosp3010010

Academic Editor: Brian Garrod

Received: 31 December 2021

Accepted: 27 January 2022

Published: 2 February 2022

Publisher's Note: MDPI stays neutral with regard to jurisdictional claims in published maps and institutional affiliations.

Copyright: (C) 2022 by the author. Licensee MDPI, Basel, Switzerland. This article is an open access article distributed under the terms and conditions of the Creative Commons Attribution (CC BY) license (https:// creativecommons.org/licenses/by/ $4.0 /)$
Program of Convergence Tourism Management, School of Future Convergence, Hallym University, Chuncheon 24252, Korea; youninj77@gmail.com; Tel.: +82-10-3317-9583

\begin{abstract}
This study aimed to analyze the competitive relationship among meetings, incentive, convention, and exhibition (MICE) destinations with reference to the notion of niche businesses in New Zealand, and to explore the existence of cooperative strategies between neighboring destinations. The data were collected from the Ministry of Business, Innovation, and Employment Reports on the Convention Activity Survey (CAS) in New Zealand. The study contributes towards an innovative and better understanding of the dynamics of sustainable destination competitiveness. It broadens the scope of MICE industry research by exploring new insights on the notion of destination competition and makes a theoretical connection between niche theory and the importance of coopetition. By investigating the case of MICE destinations of four central cities in New Zealand, this study provides information on the strategic significance of niche marketing for global destinations preparing for entrance into this market.
\end{abstract}

Keywords: niche theory; sustainable MICE destination; coexistence; coopetition; competitiveness

\section{Introduction}

The MICE (meeting, incentives, convention, and exhibitions) industry has grown significantly in recent years due to tourism being an important force driving the global economy [1]. Awareness of this economic potential has led numerous local and national governments to devote resources to the development or expansion of MICE facilities [2]. However, the boom in MICE facility development does not always show results for local economies [3]. Evidence of destructive market forces in mature economies, characterized by increased competition and price deflation from overcapacity [4], should prompt policy analysts and MICE sector managers to reconsider their strategies. In the era of globalization, firms and organizations seek new opportunities in new markets and businesses for competitive advantage [5], and competition for MICE business has shifted from competition among firms to competition among destinations [6]. In an ever-increasingly saturated market, the fundamental task for destination managers is to understand how competition can be enhanced and sustained [7] resulting in a strong need to explore competitive advantage and to analyze actual competitive positions [8].

The necessity for effective destination positioning strategies to make destination choices available to consumers has increased, along with the recognition that an essential factor for the success of a destination is its ability to compete against other destinations by identifying and developing its competitive advantage [9]. However, existing studies on MICE destination management have not filled the research gap for event management authorities on finding their competitive niche position (market). They need to create desirable coexistence circumstances and develop a plan to reduce competition failure. Current MICE destination competitiveness studies have mainly focused on the criteria and attributes to satisfy the consumer from the demand side [10-15]. They have also examined a destination's brand strategies for its attractiveness [16,17] by considering (re)visits and attracting 
business events, thus leading to fierce competition among destinations; however, these are short-term opportunistic strategies rather than integrated destination development strategies [18]. Thus, differentiated strategies should be developed by investigating what events best fit the existing infrastructure, markets, and products of a destination, so that the destination is able to establish desirable competitive and co-existing circumstances by avoiding unsustainable competition.

Developing cooperation with other parties within a network is an important strategy to increase the sustainable competitive advantage for any organization in a tourism destination [19]. Spatial proximity in a tourism destination drives businesses to develop cooperation by gaining shared resources and achieving common objectives [20]. Along with the growing awareness that competition and cooperation in business life can develop into a new co-evolution pattern [21], as well as service co-creation [22] and "coopetition" [23,24], especially in tourism destinations, competition is balanced with cooperation [25]. Since tourism destinations are typically comprised of numerous small businesses in spatial proximity competing with one another, these firms also need to cooperate to attract visitors by combining their limited marketing resources and competing with other destinations. Interestingly, the higher the level of complementarity between tourism services, the more firms will engage in collaboration despite being direct competitors [5]. According to interdestination competitive dynamics, severe competition among destinations within a region weakens the overall effectiveness and efficiency of regional tourism development [20]. Having a neighboring destination with a competitive offer might not be a threat but may create opportunities for competitors [5]. It is true that destination managers cannot control their businesses to compete or cooperate with each other in a free society, as many stakeholders are often involved with their own aims, goals, and motivations, which have to co-exist [26]. However, it is necessary for MICE destination managers to suggest a brief landscape of co-existence and cooperative strategies between neighboring destinations and to understand potential cooperative partners [27].

This study addresses the following research objectives. First, it aims to analyze the competitive relationships in MICE destinations and explore which advantageous position they should have with reference to niche theory. The niche theory is an effective way to investigate the inter-competitive relationship within a single industry, as it supports coexistence according to the extent of competition among organizations within a population. Second, this study aims to explore cooperative strategies between neighboring destinations by analyzing which destination has complementary resources since, based on the resourcebased view of "coopetition", the competitor who has similar or complementary resources could be a good partner [28]. Finally, this study presents theoretical contributions to extend the academic background in MICE research derived from adopting the niche theory, which has not been broadly applied to the MICE industry. It also presents managerial implications for establishing marketing strategies for a MICE destination and stakeholders.

\section{Literature Review}

\subsection{Competitiveness in MICE Destination}

Competitiveness in the tourism literature as a crucial factor for the success of tourist destinations seems to imply that by being competitive a tourist destination could expand, and hence improve the populace's quality of life [29]. Hong defines tourism competitiveness as the ability of a destination to create, integrate, and deliver tourism experiences, including value-added goods and services considered important by tourists [30]. These experiences sustain a destination's resources and help maintain a sound market position relative to other destinations.

Studies on MICE destinations' competitiveness are rare compared to the literature on tourism destinations, even though the underlying theoretical points are similar from a hospitality industry perspective [31]. One research trend is to examine the MICE site selection criteria, where specific variables that influence the choice of criteria have been investigated. Crouch and Ritchie grouped 36 destination attributes into a set of eight pri- 
mary categories: Accessibility, local support, extra conference opportunity, accommodation facilities, meeting facilities, information, site environment, and others [32]; these govern the choice of a convention site by other authors [10,11,14,15,33-35]. Jo, Park, Choe, and Kim identified 24 important attributes affecting international association meeting destination selection by refining Crouch and Ritchies' model [1]. Qu and colleagues studied the competitiveness of Hong Kong as an international conference destination and concluded that accommodation, convention facilities, accessibility, safety, and infrastructure were important site selection criteria [36]. Mahadewi, Bendesa, and Antara investigated seven indicators, namely, meeting facilities, hotels, accessibility, entertainment, infrastructure, and airport facilities, as latent exogenous variables of Bali as a MICE destination [17].

Another research trend is to examine the strengths and weaknesses of destinations to inform policymakers and industry partners of how to best use their strengths to overcome their weaknesses in the development of a successful MICE destination [37]. Sangpikul and Kim investigated the barriers impeding the success of Thailand's meeting and convention industry through qualitative interviews with industry stakeholders [38]. Yoo examined the attractiveness of South Korea as a convention destination via SWOT analysis and found strengths such as accessibility, geographic diversity, newly built convention facilities, and advanced technology, and weaknesses such as rising hotel rates, skilled staff shortages, poor English proficiency, and negative media images [39].

Baloglu and Love examined the important attributes among five cities in the U.S. perceived by meeting planners and identified their strengths and weaknesses and the importance of perceptual dimensions in terms of marketing, positioning, and communication strategies [40]. Nadkarni and Leong estimated the perception gap between critical attributes and performance for Macao as a MICE venue via IPA analysis [41]. McCartney studied the key perceptual development considerations for Macao's convention and exhibition industry, and revealed that re-branding and infrastructure development were required to enhance Macao's success and attractiveness as a MICE destination [13]. However, there are some weaknesses in the above studies, such as the limitation of comparing only two cities [36], the focus on surveying mainly meeting planners or other stakeholders [40], and descriptive analyses using case studies of each destination's infrastructure or competencies analysis [39]. Most studies did not address the unique and distinctive set of competitiveness indicators of the various destinations, even though competitive advantage depends on the destination's ability to use these resources effectively in the long term.

This study regards "MICE data" as a unique resource for MICE destination competitiveness. MICE destination marketing aims to attract business events as frequently as possible. However, simultaneously, the most important issue is how to partition the available resources and plan business events among venues. Moreover, specialization in a narrower range of tasks benefits a destination's productivity and performance. Akerman and Py suggested that a number of specific niche resource dimensions would inform longterm competitiveness [42]. Therefore, this study addresses the competitive relationship among destinations through the level and direction of competitiveness. This approach is unexplored in the literature, even though there is a consensus that competitor actions have a direct impact on organizations or cities. Niche positioning and bio-ecological niches are useful lenses through which to examine this issue.

\subsection{Niche Theory Application to MICE Destination}

The notion of a niche can refer to the possibility of coexistence or extinction when two venues or destinations compete for the same resources in a defined environment [43]. The concept of a niche in this theory does not denote a proportion of the population but a population's relationship with its environment [44]. In biology and evolution, the term indicates how a population or individual responds to the distribution of resources and competitors in an ecosystem. The notion of a niche originally developed from biology and evolution science, has been widely used in studies of the advertising industry to examine competition among mass media outlets [45], and can be applied "in any situation 
in which clearly defined populations compete for limited resources" ([46], p. 14). Nelson and Winter demonstrated that niche theory applies to trends in product competition [47], while McPherson extended the concept of niche overlap in ecology to develop a method for measuring competition among non-profit organizations that compete for members [48]. Kim and Park investigated competitive relationships among Korean public relations companies using niche theory [49]. Thus, this theory is useful for measuring competition among MICE destinations.

The niche in a resource domain is usually assessed using three conceptual measures: Niche breadth, niche overlap, and competitive superiority [50]. This study only investigated niche overlap and breadth as two key concepts in the spatial model of niche activities; it relates the niche to the environment and other populations in the community [51]. Comparative superiority weights competitive exclusion against displacement and better fulfills consumer gratification dimensions under competitive exclusion [52]. However, this is not the focus of this study. Niche breadth entails the extent to which a destination satisfies a relatively broad or narrow spectrum of business-event-related needs. This can be interpreted as relative specialism or in generalist terms. Specialists satisfy a relatively narrow set of needs, while generalists satisfy a broader spectrum [53]. Niche overlap, or the extent to which destinations are perceived as similar, is indicated by the 'distance' between their dimension niches. Since the values of niche overlap measures denote the degree to which two destinations depend on the same resources, they serve as an indicator of the measure of competition among resources [51].

The MICE industry entails several other resources pertaining to a destination's environment, such as infrastructure and economic or social ripple effects produced in the destination by MICE activities. This study explores the volume of MICE events according to event type, customer type, and delegate origin as multifaceted resource dimensions, since the volume of MICE events related to a venue is likely linked to the long-term survival of the destination due to their economic effects. Furthermore, the analysis of niche dimensions regarding event and customer types facilitates an improved understanding of competitors' environments or characteristics. We explore how the four MICE destinations in the Waikato and Bay of Plenty region of New Zealand could both compete and complement each other to attract a limited number of business events. Geography plays a key role in enhancing competitiveness when competitiveness resides in the capacity to define the economically relevant territory with other areas, which is not treated as a mere competitor [54]. The competitive success of one place is not always at the expense of another, and poor performance in one city may negatively impact other cities in the same network. Business events in Hamilton economically benefit neighboring cities within close proximity, such as Taupō, Rotorua, and Tauranga, by sharing services and products, such as accommodation, restaurants, and selling souvenirs.

Each of the populations in the business community aims to occupy a unique place in these multidimensional spaces, which means that a complex relationship exists among various types of interaction within an environment. Similarly, as the MICE industry is convergent with complicated actors and stakeholders based on the industrial network with private and public sectors [3], cities wishing to attract MICE events need to understand the unique niches of MICE sectors corresponding to their destination's environment and characteristics.

This study regards the business event type, customer type, and delegate origin as multidimensional niches for an analysis of the MICE sector's competitive relationship among destinations. Conference organizers and delegates are the key activators for site selection and are influenced by risks, the competitive environment, overall economic, social, and political trends and conditions, the geographical distribution of the market (i.e., size, accessibility), characteristics of the client or organization, its budgets and objectives, the evaluation of time-distance and cost-distance of the catchment area, the type of meeting, and so on [55]. The exploration of the different types of customer, event, and delegate characteristics typically used by these destinations enables the description of a destination's 
environmental MICE characteristics. Thus, the volume of business events with reference to customer type, event type, and delegate has been adopted for niche analyses of the MICE industry.

\subsection{Coopetition and Niche Theory}

In management, marketing, and tourism studies, competition and cooperation have recently been juxtaposed to "coopetition" [23]. This term has been used by many researchers [56] who insist that organizations do not always engage in either competitive or cooperative relationships, but these often co-exist. Bengtsson and Kock suggest that a cooperative dyadic relationship is established when two competitors cooperate in a strategic alliance for product development, while simultaneously competing in the marketing of the resulting products [56]. Coopetition can be defined as cooperating to create a bigger business pie while competing to divide it [24]. It is also a strategic and dynamic process in which economic actors jointly create value through cooperative interaction, while simultaneously competing to capture part of that value [57].

In the neoclassical economic theory, people have rational preferences to maximize their utility through competition, but over time, it has become evident that there are not only win-lose situations, but also win-win and lose-lose situations that might be adopted by players [5]. The notion of coopetition has two concepts, namely, a win-win strategy and lose-lose risk, based on the extent of sharing resources and knowledge as advantages to be obtained from both competition and cooperation [58]. Thus, the extent of resource sharing between competitors who have similar or complementary resources determines the success of the collaboration [28]. Organizations successfully complete paradoxical processes and focus on their value creation by regarding competitors as complementary and collaborating with their various resources and capabilities, thus increasing the success potential of coopetition [56]. The assumption is that many players may complement each other by avoiding mutually destructive strategic behaviors and achieving win-win conditions, even if they are competitors.

Based on a resource-based perspective, the coopetition approach links with the competitive advantage object, which is searching for the resources and capabilities necessary to obtain value-enhancing strategies to gain revenue above their opportunity cost [27]. Opportunity cost refers to the returns drawn from coopetition strategies over those of the best alternative; the results depend on the use, allocation, and exchange of resources [25]. The foremost premise for coopetition between players is first to possess complementary resources or technologies [59], and second, to have an optimal level of tension and competition between players [60].

Thus, niche theory, which can explain competitive relationships, the level of competition (via niche overlap), and resource usage patterns (via niche breadth) among competitors, enables an understanding of the notion of a coopetition strategy, as niche overlap is considered an index of the substitutability of the complementarity of two players [61]. A lower overlap reflects that two organizations serve very different needs and that a greater sense of complementarity exists between them, meaning that they may adopt coopetition as a strategy. Cho and Lee confirm through network analysis that both firms that serve a specialized market with low levels of competition and firms that are highly competitive with similar resources have low cooperative willingness [62]. Thus, the analysis of niche overlap and breadth enables an understanding of which destination pairs should adopt a coopetition strategy.

This study explores cooperative strategic suggestions by focusing on the Waikato and Bay of Plenty region of New Zealand, namely, Hamilton, Tauranga, Rotorua, and Taupō. While this tourism destination is considered a business agglomeration and industrial district [63], the co-location, proximity, and interconnectedness of local tourism companies of different sizes create possibilities for businesses to cooperate while competing [23]. Having a neighboring destination with a competitive offer might not be a threat, and may create opportunities even if too much competition among destinations within a 
region weakens the overall effectiveness of regional tourism development [20]. Moreover, geographic proximity, co-location, and the consequent formation of micro clusters are sources of unintentional coopetition [27]. Destination management organizations usually favor both intentional and unintentional cooperative connections, thus creating more versatile strategic options.

The research questions first explore niche breadth and overlap among four MICE destinations by event type, customer, and delegate origin, and second, explore which destination pairs within four cities are better suited to adopt coopetition strategies for their competitive advantage and sustainability.

\section{Methodology}

\subsection{Sample and Data Collection}

The sample for this research was collected from the Ministry of Business, Innovation, and Employment (MBIE) reports for the Convention Activity Survey (CAS), which measures business event activity at qualifying venues in New Zealand from 2011 to 2018. CAS is part of a broader convention research program, measures the business event activity at 13 qualifying venues, which has the convention bureaus in New Zealand. The qualified venues included in CAS are classified into five types: Event or convention centers, stadium/showgrounds, hotels, other forms of accommodation (such as motels, motor lodges, and the like), and other venues (including restaurants, vineyards, and theaters). These participants had to promote their venues as suitable for a range of business-related activities, especially conventions/conferences and meetings; they had to have a theaterstyle venue with a minimum capacity of 50 people and aim or plan to host a minimum of 12 conventions and/or business-related events each year.

Events are also classified into five types: Meeting/seminar, that is a formal gathering of people to discuss matters of shared of interest usually within a single session; incentive activities defined as activities that incentivize or reward the invited event delegates for exceptional business achievement; conference/convention (a formal gathering of people to discuss shared interests involving multiple sessions and speakers); trade shows/exhibition (showcases of goods and services held for the benefits of a specific industry); and special occasion activities, which are social gatherings or celebrations such as gala dinners, balls, graduation ceremonies, cocktail parties, birthday parties, or weddings. The customer types are classified into associations, business, government, education, personal, and others, while delegate origins are classified into local, regional, international, or Australian.

\subsection{Analysis of Niche Dimension}

As discussed above, niche breadth refers to the variety of categories within a resource domain consumed/exchanged through the MICE destinations. In this study, the resource dimensions are the type of customer, type of event, and delegate. According to the Dimmick, Patterson, and Albarran research theory [46], the niche breadth formula can be calculated as shown in Equation (1).

$\mathrm{Pi}$ represents the proportion of the total volume of MICE events in each resource category $i$ (e.g., meeting/seminar, incentive activities, conference/convention, tradeshow/exhibition, special occasions) used by population A (such as Auckland or Hamilton). Three resource dimensions are calculated with this formula. Lower values of $B$ indicate that business event types are concentrated in fewer categories. Niche overlap is a measure of how similar two destinations are with regard to the holding of MICE event resources they attract and is generally regarded as an index of ecological similarity, which can often be interpreted as indicating competition between two populations. The niche overlap for two populations can be calculated as presented in Equation (2):

$$
B=\frac{1}{\sum_{i=1}^{m} P i^{2}}
$$




$$
d i j=\sum_{i=1}^{m}(P i, h-P j, h)^{2}
$$

where the term dij denotes the distance between destinations $i$ and $j, h$ represents the resource categories by event type, customer type, and delegate origin; $P i, h$ is the proportion of destination $j^{\prime}$ s total volume of MICE events in each resource category, $P j, h$ is the proportion of destination $j$ 's total volume of MICE events in each resource category, and $\mathrm{m}$ is the mean value. If the geometric distance is equal to a value of zero, there is perfect overlap or perfect similarity in resource use. Values that are higher than zero denote less overlap or ecological similarity in resource use [51]. Above equations show the calculation model of the niche breadth and overlap.

\section{Results}

Analyzing the New Zealand Convention Activity Survey reports from 2011 to 2018 showed that the total volume of all business events held in New Zealand was 363,245 (45,445 on average per year). More than $32 \%$ of these were in Auckland, around 16\% in Wellington, while Christchurch and Hamilton collectively shared third place (Table 1). Meetings or seminars displayed the highest volume by event type (almost exceeding $60 \%$ ), and special occasion events ranked next with approximately $20 \%$ on average across all cities, but the ratios differed between cities. Business events (approximately 50\%) ranked first and association events (approximately 12\%) second in total volume by customer type averaged over the cities. Almost $30 \%$ of these were held in Auckland, while approximately $15-17 \%$ were held in Wellington. The total number of delegates was 26.2 million and averaged 3.2 million throughout the eight years (2011 to 2018) at all business events in New Zealand. Over $95 \%$ were domestic and local delegates, and an average of $36 \%$ of the total volume of delegates was in Auckland. Approximately 17\% took place in Wellington (second place), and Christchurch and Hamilton ( $9 \%$ on average) were in third place throughout the year. However, Queenstown was ranked second for international delegates, followed by Auckland (Appendixs A, B and C). If Hamilton, currently positioned fourth in terms of volume, has a cooperative strategy with Taupō, Rotorua, and Tauranga, they would rank second, followed by Auckland.

Table 1. Total volumes of event data for eight years (2011-2018).

\begin{tabular}{ccccc}
\hline \multirow{2}{*}{ Cities } & \multicolumn{2}{c}{ Total N. of Events } & \multicolumn{2}{c}{ Total N. of Delegates } \\
\cline { 2 - 5 } & Total Number & $\mathbf{M ~ ( \% )}$ & Total Number & $\mathbf{M ~ ( \% )}$ \\
\hline AUC & 114.528 & $14.320(32)$ & $9,532,317$ & $1,191,540(36)$ \\
TAR & 16,621 & $2078(5)$ & $1,128,679$ & $141,085(4)$ \\
C\&C & 35,594 & $4449(10)$ & $2,335,567$ & $291,946(9)$ \\
DUN & 11,582 & $1448(3)$ & 764,795 & $95,599(3)$ \\
HAM & 34,864 & $4358(10)$ & $2,235,532$ & $279,441(9)$ \\
HAWK & 11,334 & $1417(3)$ & 661,998 & $82,750(3)$ \\
MANA & 27,896 & $3487(8)$ & $2,031,462$ & $253,933(8)$ \\
MARL & 5461 & $683(2)$ & 310,455 & $38,807(1)$ \\
NELS & 12,021 & $1503(3)$ & 695,972 & $86,996(3)$ \\
QUEEN & 9997 & $1250(3)$ & 570,218 & $71,277(2)$ \\
ROT & 15,214 & $1902(4)$ & 999,455 & $124,932(4)$ \\
TAU & 9451 & $1181(3)$ & 374,872 & $46,859(1)$ \\
WELL & 58,651 & $7331(16)$ & $4,571,867$ & $571,483(17)$ \\
Total & $\mathbf{3 6 3 , 2 4 5}$ & $\mathbf{4 5 , 4 4 5 ( 1 0 0 )}$ & $\mathbf{2 6 , 2 1 3 , 1 8 8}$ & $\mathbf{3 , 2 7 6 , 6 4 9 ( 1 0 0 )}$ \\
\hline
\end{tabular}

AUC: Auckland, TAR: Tauranga, C\&C: Christchurch and Canterbury, DUN: Dunedin, HAM: Hamilton, HAWK Hawkes Bay, MANA: Manawatū, MARL: Marlborough, NEL: Nelson, QUEEN: Queenstown, ROT: Rotorua, TAU: Taupō, WELL: Wellington.

Niche breadth and overlap analyses were analyzed by focusing on the Waikato and Bay of Plenty region of New Zealand, namely, Hamilton, Tauranga, Rotorua, and Taupō. The niche breadth values among the four MICE destinations in the event type resource 
dimension are reported in Tables 2 and 3. Examining the means of the niche breadth values throughout the entire period, Hamilton $(\mathrm{M}=1.896)$ appeared to be a relative specialist in this domain by focusing on the meeting/seminar category, except in 2011 and 2018. Rotorua became more generalist from 2015 to 2017, being on average generalist $(M=2.615)$ throughout the year by broadening their market to social occasion events (see Table A1). Hamilton seeks a specific niche strategy in the meeting/seminar category, and Rotorua and Taupō are relatively generalists with broad niches in the event type dimension.

Table 2. Niche breadth by the resource dimensions.

\begin{tabular}{|c|c|c|c|c|c|c|c|c|c|c|}
\hline Div. & Cities. & 2011 & 2012 & 2013 & 2014 & 2015 & 2016 & 2017 & 2018 & Mean \\
\hline \multirow{4}{*}{ 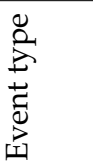 } & TAR & 2.691 & 2.273 & 2.136 & 2.196 & 2.062 & 1.984 & 1.994 & 2.111 & 2.181 \\
\hline & HAM & 2.107 & 1.995 & 1.939 & 1.868 & 1.817 & 1.856 & 1.757 * & 1.826 & 1.896 * \\
\hline & ROT & 2.814 & 2.399 & 2.380 & 2.567 & 2.653 & $2.832 * *$ & 2.533 & 2.740 & $2.615 * *$ \\
\hline & TAU & 2.751 & 2.619 & 2.340 & 2.778 & 2.438 & 2.547 & 2.245 & 2.722 & 2.555 \\
\hline \multirow{4}{*}{ 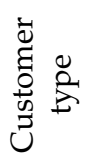 } & TAR & 3.481 & 3.449 & 3.841 & 4.506 & 4.554 ** & 4.155 & 3.492 & 3.148 & 3.828 \\
\hline & HAM & 2.640 & 3.036 & 3.084 & 3.762 & 3.673 & 3.340 & 2.991 & 2.910 & 3.179 \\
\hline & ROT & 2.826 & 2.984 & 3.797 & 3.995 & 3.812 & 4.554 & $4.635 * *$ & 4.187 & $3.849 * *$ \\
\hline & TAU & 2.650 & 3.100 & 3.092 & 4.036 & 3.916 & 4.064 & 3.241 & 3.634 & 3.467 \\
\hline \multirow{4}{*}{ 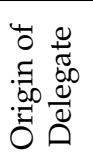 } & TAR & 1.650 & 1.481 & 1.649 & 1.673 & 1.580 & 1.662 & 1.602 & 1.436 & 1.592 \\
\hline & HAM & 1.408 * & 1.446 & 1.548 & 1.457 & 1.502 & 1.543 & 1.493 & 1.470 & 1.483 * \\
\hline & ROT & 2.325 & 2.185 & $2.405 * *$ & 2.300 & 2.294 & 2.409 & 2.290 & 2.340 & $2.318 * *$ \\
\hline & TAU & 2.278 & 2.151 & 2.050 & 2.069 & 2.140 & 2.321 & 2.154 & 2.074 & 2.154 \\
\hline
\end{tabular}

Table 3. Niche overlap by event type.

\begin{tabular}{ccccccc}
\hline Yr. & TAR/HAM & TAR/ROT & TAR/TAU & HAM/TAR & HAM/TAU & TAR/TAU \\
\hline 2011 & 0.020 & 0.028 & 0.008 & 0.035 & 0.020 & 0.006 \\
2012 & 0.007 & 0.010 & 0.012 & 0.016 & 0.029 & 0.005 \\
2013 & 0.005 & 0.012 & 0.018 & 0.017 & 0.023 & $\mathbf{0 . 0 0 1}$ \\
2014 & 0.011 & 0.022 & 0.082 & 0.043 & $\mathbf{0 . 1 0 4} * *$ & 0.021 \\
2015 & 0.010 & 0.034 & 0.033 & 0.049 & 0.043 & 0.002 \\
2016 & 0.002 & 0.068 & 0.024 & 0.093 & 0.036 & 0.019 \\
2017 & 0.006 & 0.033 & 0.005 & 0.065 & 0.020 & 0.018 \\
2018 & 0.003 & 0.058 & 0.033 & 0.098 & 0.068 & 0.024 \\
$\mathbf{M}$ & $\mathbf{0 . 0 0 8} *$ & $\mathbf{0 . 0 3 3}$ & $\mathbf{0 . 0 2 7}$ & $\mathbf{0 . 0 5 2} * *$ & $\mathbf{0 . 0 4 3}$ & $\mathbf{0 . 0 1 2}$ \\
\hline
\end{tabular}

${ }^{*}$ High competition, ${ }^{* *}$ Low competition.

In terms of niche overlap pertaining to the event type resources reported in Table 3, the Tauranga/Hamilton (0.008) pair has the highest competitive value with similar resources such as meeting/seminar and special events. In contrast, Hamilton/Rotorua (0.052) showed the lowest competition, followed by Hamilton/Taupō (0.043), suggesting that these cities are using different types of events, pointing to the possibility for this grouping to complement their resources. Thus, Hamilton and Tauranga have a similar use pattern for event type, whereas Rotorua and Taupō are more focused on the conference than the meeting/seminar dimension, both of which are competitive with each other but have low competition with Hamilton. Taupō and Rotorua should therefore cooperate with Hamilton to gain a competitive advantage by supporting each other to host events: Meetings/seminars for Hamilton, conferences in Taupō, and special social events in Tauranga and Rotorua. Having specialized niches might reduce the level of competition and allow them to complement each other in the event type resource dimension.

Tables 2 and 4 show the pattern of niche breadth and overlap among the four MICE destinations over the total volume of MICE events by five different customer types. Niche breadth values indicate that all the cities are mostly generalized, ranging from 3.179 to 3.849 on average values, which is larger than the median, and 2.5 throughout the entire period (see Table 2). The total impact of business customers is relatively high, 
but Rotorua includes other customer types and is increasingly hosting fewer business events and seeking to be generalists (see Table A2). The values of niche overlap for MICE events by customer type indicate that almost all pairs of cities demonstrated high levels of competition, reaching overlap values between 0.009 to 0.021 by focusing on strong associations and business customers (see Table A2). The Tauranga/Taupō $(\mathrm{M}=0.017)$ and Hamilton/Rotorua $(\mathrm{M}=0.021)$ pairs showed relatively lower levels of competition. Tauranga and Hamilton are similarly positioned and highly competitive within the personal and other event customer sectors. Therefore, coopetition between Rotorua and Hamilton while supporting education in Hamilton and the personal and other sector in Rotorua with a co-marketing strategy would improve their mutual growth in the total number of events.

Table 4. Niche overlap by customer type.

\begin{tabular}{ccccccc}
\hline Yr. & TAR/HAM & TAR/ROT & TAR/TAU & HAM/TAR & HAM/TAU & TAR/TAU \\
\hline 2011 & 0.024 & 0.013 & 0.021 & 0.002 & 0.008 & 0.008 \\
2012 & 0.006 & 0.006 & 0.007 & $\mathbf{0} *$ & 0.009 & 0.009 \\
2013 & 0.010 & 0.006 & 0.019 & 0.020 & 0.016 & 0.016 \\
2014 & 0.007 & 0.007 & 0.038 & 0.003 & 0.037 & 0.037 \\
2015 & 0.011 & 0.012 & 0.018 & 0.004 & 0.017 & 0.017 \\
2016 & 0.008 & 0.021 & 0.010 & 0.042 & 0.016 & 0.016 \\
2017 & 0.004 & 0.043 & 0.007 & $\mathbf{0 . 0 6 4} * *$ & 0.009 & 0.009 \\
2018 & 0.002 & 0.028 & 0.013 & 0.034 & 0.018 & 0.018 \\
$\mathbf{M}$ & $\mathbf{0 . 0 0 9 *}$ & $\mathbf{0 . 0 1 7}$ & $\mathbf{0 . 0 1 7}$ & $\mathbf{0 . 0 2 1} * *$ & $\mathbf{0 . 0 1 6}$ & $\mathbf{0 . 0 1 6}$ \\
\hline
\end{tabular}

* High competition, ${ }^{* *}$ Low competition.

Tables 2 and 5 indicate the distribution patterns of the total volume of MICE events by delegate origin in terms of niche breadth and overlap for the four MICE destinations. Rotorua and Taupō were mostly generalists with 2.315 and 2.154, respectively, while Hamilton and Tauranga had a relatively high degree of specialization, with 1.483 and 1.592 , respectively. The overlap value of the delegate origin dimension indicates that the Tauranga/Hamilton pair has comparatively high competition levels with a value of 0.004 because they compete for similar local and domestic delegates (see Table A3). Hamilton/Taupō $(M=0.210)$ showed the lowest competition, followed by Tauranga/Taupō $(\mathrm{M}=0.177)$, meaning that these destinations focus on different delegate origin dimensions. This suggests a sound possibility for complementarity in terms of resources. However, since Taupo has comparatively high competitiveness in this dimension with reference to all of New Zealand, their intention to strategically cooperate with other cities to share delegates is likely low. Rather, coopetition between Hamilton and Rotorua would be more realistic, as both demonstrate modest levels of overlap $(\mathrm{M}=0.122)$ in the delegate origin dimension.

Table 5. Niche overlap by delegate origin.

\begin{tabular}{ccccccc}
\hline Yr. & TAR/HAM & TAR/ROT & TAR/TAU & HAM/TAR & HAM/TAU & TAR/TAU \\
\hline 2011 & 0.009 & 0.105 & 0.155 & 0.175 & 0.237 & 0.005 \\
2012 & $\mathbf{0} *$ & 0.084 & 0.218 & 0.091 & 0.228 & 0.035 \\
2013 & 0.002 & 0.071 & 0.328 & 0.094 & $\mathbf{0 . 3 7 6} * *$ & 0.106 \\
2014 & 0.012 & 0.071 & 0.328 & 0.094 & $\mathbf{0 . 3 7 6} * *$ & 0.106 \\
2015 & 0.001 & 0.104 & 0.111 & 0.124 & 0.132 & 0.002 \\
2016 & 0.003 & 0.119 & 0.107 & 0.161 & 0.146 & 0.001 \\
2017 & 0.002 & 0.093 & 0.075 & 0.124 & 0.103 & 0.002 \\
2018 & $\mathbf{0 . 0 0 0 *}$ & 0.129 & 0.094 & 0.117 & 0.083 & 0.005 \\
$\mathbf{M}$ & $\mathbf{0 . 0 0 4} *$ & $\mathbf{0 . 0 9 7}$ & $\mathbf{0 . 1 7 7}$ & $\mathbf{0 . 1 2 2}$ & $\mathbf{0 . 2 1 0} * *$ & $\mathbf{0 . 0 3 3}$ \\
\hline
\end{tabular}

* High competition, ${ }^{* *}$ Low competition.

\section{Discussion}

The study results provide a fine-grained analysis of the relationships that extend beyond competitive contexts. Niche theory is capable of dealing with such complexity 
and offers a fine-grained set of techniques for strategic alternatives that overcome the limitations of other studies. Our key findings outline the significance of niche breadth and overlap measures of competition for resources on multiple dimensions for a population of organizations in an economic sector, within a bounded region influenced by common political, social, and economic environmental conditions. By applying niche theory to explain the comparative relationship among the four central cities' MICE destinations in New Zealand, this study provides important results and contributes to the understanding of MICE tourism that can be applied globally.

First, it demonstrated that four cities generally share similar resources in the event and customer type, and delegate origin dimension, since all are mainly focused on meetings/seminars, business events, and local delegate attraction, resulting in comparatively high competition between Hamilton/Tauranga. Hamilton/Rotorua or Taupō showed relatively low competition in terms of event type because Rotorua and Taupō have focused on conferences and conventions, avoiding the high occupation of meetings/seminars. Low overlap and a relatively specialist strategy are suitable for the most appropriate competitiveness. Hamilton, as a specialist, is required to adopt a cooperative strategy with Rotorua or Taupō by reducing competition with Tauranga. They would thus have a competitive advantage in the central area of New Zealand.

Second, the relative extent of the competitive relationship between pairs of cities differs by year according to their resource usage pattern. This study demonstrated that the level of competition is reduced when they alter their niche dimension by escaping from concentrating on resources. Rotorua has had a low level of competition with other cities since 2015 due to its attractiveness for special social events. Tauranga failed to avoid a fiercely competitive situation since they focused too heavily on concentrated resources such as meetings/seminars and business customers, which are mostly shared by others. This result supports the argument that to sustain competitiveness, an actual competitive position must be found; if each city is selective and differentiates their markets vis-a-vis each other to identify their competitive position and environmental conditions, they might avoid high levels of competition [8].

Third, at higher densities, competition is stronger, there is higher mortality, potentially reduced funding rates, and possible extinction should be anticipated if policy and strategic planning do not curb growth. Hence, it is essential that inter-organizational collaboration occurs in research activities, defining shared goals and measuring impact [62]. Hamilton has survived amidst strong competition from other cities by concentrating on meetings/seminars within the education field by cooperating with Rotorua, which results in reduced competition. Hamilton should abandon the social occasion and conference sectors. Tauranga should cooperate with Taupō while concentrating on conferences for Taupō and social events for Tauranga. Thus, this study revealed that Hamilton vs. Rotorua and Tauranga vs. Taupō are better suited to the adoption of a coopetition strategy using niche overlap as an index of complementarity for the two players.

In summary, competitive and co-existent relationships were identified using niche theory focused on micro-dimensional niche characteristics such as customer and event type, and delegate origin. Coexistence depends on the factors of customer characteristics and volume of customer segments; competition depends on the level of common resources that they have control over. Thus, this study provides a more nuanced view of destination competition; they are affected by the total volume of MICE events, but coexistence depends on customer and event type. These results have implications for the future of the MICE industry and its long-term viability.

\section{Conclusions}

\subsection{Theoretica Contribution}

As competition continues to grow with globalization, establishing an appropriate position with a competitive advantage and sound understanding of working relationships among destinations is very important for collaborative destination marketing [25]. This 
study contributes to the business events literature by exploring how each MICE destination in New Zealand occupies a competitive position in their respective niche markets. This is carried out by analyzing multi-dimensional resources using patterns. This study also offers suggestions as to how destinations can develop cooperative strategic partners among neighboring competitors, especially in the central North Island. Our analysis contributes to scholarly literature in the field in several ways.

First, it contributes to a better understanding of the dynamics of destination competitiveness and broadens the scope of MICE industry research by applying mass media communication theories to business communication to explain the competition and coexistence of MICE destination relationships. This contribution can form a foundation from which to expand the application of these theoretical concepts to the hospitality and tourism industry. For example, the hotel industry also competes for limited resources such as business and leisure tourists, accommodation prices, location, and so forth. To evade competition and find a strategic niche, they need to know their competitors, identify their niche positions, and explore alternatives to competition. Hence, this study suggests an adaptation of niche theory beyond the MICE industry. By applying readily available secondary data that have not been previously used in this manner, this study identified new resource dimensions with which to examine the competitive relationships in MICE destinations that transcend the limited measures of destination attributes and selection criteria used in previous studies based on customer perceptions.

Second, this study explores the competitive relationships between local destinations within a nation, rather than the commonly addressed international competition. The top-tier city in the MICE industry may be focused on international competition, but the second- or third-tier cities are mostly interested in competing with local opponents for internal markets. Thus, this study may yield a number of significant benefits for second-tier destinations in terms of how to find niche positions for long-term survival and coexistence.

Third, it extends niche theory by developing a new term, the notion of a strategic niche, and a way of visualizing niche breadth, which has not been discussed in prior research that has mainly focused on one-dimensional comparisons of destinations, features, and services based on the absolute evaluation of a specific criterion, or the economic impacts that have not addressed organic relationships, both of which were achieved by this study. Future research could examine such environmental variations to establish their impacts.

Finally, this study pioneers the significant theoretical notion that niche theory, which has been applied to competitive relationships, could explain coopetition, even though it only focuses on the Waikato and Bay of Plenty region of New Zealand. It also presents a new approach towards coopetition using niche overlap value together with niche theory, and links both conceptually since most coopetition research in tourism and hospitality literature tends to opt for conceptualization, literature reviews, and qualitative approaches, with mostly single or multiple case studies [55].

\subsection{Managerial Implications}

The findings of this study provide several practical insights into destination management in the industry context.

First, most cities in New Zealand lie in the high-competition business-event market; the average niche overlap ranged from 0.01 to 0.07 with reference to event and customer type dimensions. Although there is a very high degree of overlap between them regarding the resource dimensions under analysis, the different consumer usage patterns found in this study (differences in the niche) allow four MICE destinations to coexist. For example, Hamilton is competitively positioned with a narrow niche breadth and low niche overlap with Rotorua and Taupō in terms of event dimensions, especially regarding specializing in meetings/seminars.

Second, this study suggests that destinations should find the appropriate niche dimensions necessary for sustainable strategic survival in the fiercely competitive MICE industry. For example, Taupō needs to attract more conferences among different business 
event categories to bypass the strong competition in the event type dimension. Similarly, Hamilton and Rotorua/Tauranga should focus on education customer business events and social occasions, respectively.

Third, with the consistent growth in global MICE events, this result would have strategic significance in niche marketing for a destination preparing to enter and understand their potential niche market. For the government policymaker, the guideline of competition policy to assist cities to use less concentrated resources could be achieved by devoting political support to this position. This would result in improved opportunities for resource allocation to meet the needs of destinations for co-existence in a competitive environment.

Although this study investigated competition and coexistence among only four MICE destinations, it suggests that some of the destinations require strategic cooperation to benefit from the powerful, close-range competition. Some researchers indicate that organizations do not always need to engage in either competitive or cooperative relationships, but can fruitfully co-exist. The term coopetition refers to simultaneous cooperation and competition; both relationships are dependent on the closeness of their activities to the customer.

\subsection{Limitations and Further Research}

This study did not address deeper concerns because its aim was to analyze business event data provided by the Ministry of Business Innovation and Employment. If more detailed information about delegate characteristics can be obtained, the strategic positioning between Taupō and Rotorua could be developed further. Thus, future research should investigate more resource motivation dimensions, such as user gratification, infrastructure, or event themes. Second, the issue of the generalizability of the competitive relationship remains due to limited case applications such as event and customer type, and delegate origin dimensions, even though this study provides new theoretical insights and measurement tools by exploring competition intensity via niche overlaps in the coopetition literature of hospitality management. Limiting measures to a few resource dimensions and snapshots of four cities over eight years also restricts the in-depth nature of the study findings. The overall trends persisted before COVID-19. The investigation furthers our understanding of the theoretical concept and nature of the relationship between the constructs. Accordingly, this issue should be extended to other resource domains to verify the generalizability of the results. Finally, the current study did not address how we might develop substantial strategic coopetition relationships, but merely indicates the ideal relations for coopetition. However, the significance of adding one ray to deficient quantitative research will motivate further research.

Funding: This research received no external funding.

Informed Consent Statement: Informed consent was obtained from all subjects involved in the study.

Conflicts of Interest: The authors declare no conflict of interest.

\section{Appendix A}

Table A1. Total volume by event type dimension for eight years (2011-2018).

\begin{tabular}{cccccccc}
\hline Cities & M.S (\%) & Incent. (\%) & C\&C (\%) & Ex. (\%) & Special (\%) & N.A (\%) & Total \\
\hline AUC & $67,792(59)$ & $1384(1)$ & $13,474(12)$ & $1927(2)$ & $20,094(18)$ & $858(1)$ & 114,558 \\
TAR & $10,492(63)$ & $315(2)$ & $1516(9)$ & $357(2))$ & $3870(23)$ & $72(0)$ & 16,621 \\
C\&C & $24,416(69)$ & $848(2)$ & $3102(9)$ & $639(2)$ & $6373(18)$ & $216(1)$ & 35,594 \\
DUN & $7469(64)$ & $278(2)$ & $1157(10)$ & $317(3)$ & $2280(20)$ & $82(1)$ & 11,582 \\
HAM & $24,446(70)$ & $640(2)$ & $2713(8)$ & $587(2)$ & $3670(18)$ & $108(0)$ & 34,864 \\
HAWK & $7036(62)$ & $225(2)$ & $862(8)$ & $248(2)$ & $2885(25)$ & $78(1)$ & 11,334 \\
MANA & $18,575(69)$ & $479(2)$ & $2493(9)$ & $519(2)$ & $5618(20)$ & $212(1)$ & 27,896 \\
MARL & $2605(60)$ & $149(3)$ & $426(10)$ & $103(2)$ & $1017(24)$ & $6(0)$ & 4308 \\
NELS & $7364(61)$ & $454(4)$ & $1039(9)$ & $292(2)$ & $2741(23)$ & $132(1)$ & 12,021 \\
\hline
\end{tabular}


Table A1. Cont.

\begin{tabular}{cccccccc}
\hline Cities & M.S (\%) & Incent. (\%) & C\&C (\%) & Ex. (\%) & Special (\%) & N.A (\%) & Total \\
\hline QUEEN & $5315(53)$ & $669(7)$ & $1816(18)$ & $253(3)$ & $1850(19)$ & $94(1)$ & 9997 \\
ROT & $7131(47)$ & $357(2)$ & $2549(17)$ & $282(2)$ & $3830(25)$ & $123(1)$ & 15,214 \\
TAU & $5230(55)$ & $200(2)$ & $1848(20)$ & $116(1)$ & $2000(21)$ & $56(1)$ & 9451 \\
WELL & $37,077(63)$ & $987(2)$ & $9069(15)$ & $1019(2)$ & $10,082(17)$ & $417(1)$ & 58,652 \\
\hline
\end{tabular}

M.S: Meeting/seminar, Incent.; Incentive Activity, C\&C: Conference \& convention, Ex: Exhibition, trade show, N.A: Not acknowledged.

\section{Appendix B}

Table A2. Total volume by customer type dimension for eight years (2011-2018).

\begin{tabular}{|c|c|c|c|c|c|c|c|c|}
\hline Cities & Ass. (\%) & Biz (\%) & Govern. (\%) & Edu. (\%) & Pers. (\%) & Others (\%) & N.A. (\%) & Total (\%) \\
\hline \multirow{2}{*}{ AUC } & 16,147 & 64,077 & 11,234 & 9081 & 7583 & 2646 & 3767 & 114,534 \\
\hline & (14) & $(56)$ & $(10)$ & $(8)$ & $(7)$ & $(2)$ & (3) & (100) \\
\hline \multirow{2}{*}{ TAR } & 2633 & 7382 & 1848 & 1672 & 2040 & 569 & 546 & 16,691 \\
\hline & $(16)$ & $(44)$ & $(11)$ & (10) & (12) & (3) & (3) & $(100)$ \\
\hline \multirow{2}{*}{$\mathrm{C} \& \mathrm{C}$} & 5345 & 20,507 & 3034 & 2482 & 3281 & 513 & 614 & 35,775 \\
\hline & $(15)$ & $(57)$ & $(8)$ & $(7)$ & $(9)$ & (1) & (2) & $(100)$ \\
\hline \multirow{2}{*}{ DUN } & 1938 & 5122 & 1283 & 1555 & 970 & 320 & 410 & 11,597 \\
\hline & (17) & $(44)$ & (11) & (13) & $(8)$ & (3) & $(4)$ & $(100)$ \\
\hline \multirow{2}{*}{ HAM } & 4788 & 17,898 & 3431 & 3343 & 3161 & 1036 & 1140 & 34,797 \\
\hline & $(14)$ & (51) & (10) & (10) & $(9)$ & (3) & (3) & $(100)$ \\
\hline \multirow{2}{*}{ HAWK } & 1454 & 5264 & 1178 & 1094 & 1547 & 467 & 302 & 11,306 \\
\hline & (13) & $(47)$ & (10) & (10) & (14) & (4) & (3) & $(100)$ \\
\hline \multirow{2}{*}{ MANA } & 4157 & 13,595 & 2928 & 2866 & 2708 & 728 & 765 & 27,746 \\
\hline & (15) & $(49)$ & (11) & (10) & (10) & (3) & (3) & $(100)$ \\
\hline \multirow{2}{*}{ MARL } & 809 & 2425 & 504 & 394 & 552 & 314 & 118 & 5116 \\
\hline & (16) & $(47)$ & (10) & $(8)$ & (11) & (6) & (2) & $(100)$ \\
\hline \multirow{2}{*}{ NELS } & 2349 & 5023 & 1137 & 1275 & 1658 & 202 & 363 & 12,007 \\
\hline & $(20)$ & $(42)$ & $(9)$ & (11) & (14) & (2) & (3) & (100) \\
\hline \multirow{2}{*}{ QUEEN } & 1457 & 5757 & 647 & 660 & 902 & 186 & 453 & 10,062 \\
\hline & (14) & (57) & (6) & (7) & $(9)$ & (2) & (5) & $(100)$ \\
\hline \multirow{2}{*}{ ROT } & 2417 & 5843 & 1049 & 962 & 1778 & 966 & 486 & 13,501 \\
\hline & (18) & $(43)$ & (8) & (7) & (13) & (7) & (4) & $(100)$ \\
\hline \multirow{2}{*}{ TAU } & 1610 & 4503 & 627 & 431 & 1295 & 340 & 633 & 9439 \\
\hline & (17) & $(48)$ & $(7)$ & (5) & (14) & $(4)$ & $(7)$ & (100) \\
\hline \multirow{2}{*}{ WELL } & 9004 & 23,109 & 9857 & 4733 & 2994 & 1400 & 1059 & 52,155 \\
\hline & $(17)$ & $(44)$ & (19) & (9) & (6) & (3) & (2) & $(100)$ \\
\hline
\end{tabular}

Ass.: Association, Biz: Business, Govern.: Government, Edu.: Education, Pers.: Personal, N.A.: Not acknowledged. Blanks are ratio.

\section{Appendix C}

Table A3. Total volume by delegate origin dimension for eight years (2011-2018).

\begin{tabular}{lccccc}
\hline Cities & Local (\%) & Domestic (\%) & Australian (\%) & Int'1 (\%) & Total (\%) \\
\hline AUC & $5,468,874(80)$ & $1,131,096(16)$ & $118,941(2)$ & $155,609(2)$ & $6,874,520(100)$ \\
TAR & $793,445(77)$ & $217,810(21)$ & $10,025(1)$ & $15,763(2)$ & $1,037,043(100)$ \\
C\&C & $1,832,461(82)$ & $341,676(15)$ & $20,429(1)$ & $36,528(2)$ & $2,231,094(100)$ \\
DUN & $496,763(78)$ & $115,910(18)$ & $12,173(2)$ & $14,037(1)$ & $638,883(100)$ \\
HAM & $1,705,534(80)$ & $389,799(18)$ & $13,033(1)$ & $22,709(1)$ & $2,131,075(100)$ \\
HAWK & $489,696(81)$ & $104,253(17)$ & $5898(1)$ & $7605(1)$ & $607,452(100)$ \\
MANA & $1,296,871(82)$ & $261,990(17)$ & $9338(1)$ & $15,615(1)$ & $1,583,814(100)$ \\
MARL & $222,070(75)$ & $60,677(20)$ & $6898(2)$ & $6341(2)$ & $295,986(100)$ \\
NELS & $437,855(75)$ & $126,516(22)$ & $8867(2)$ & $12,356(2)$ & $585,593(100)$ \\
QUEEN & $209,307(39)$ & $193,476(36)$ & $88,501(16)$ & $49,465(9)$ & $540,750(100)$ \\
ROT & $489,976(52)$ & $364,279(39)$ & $34,328(4)$ & $46,897(5)$ & $935,480(100)$ \\
TAU & $156,820(47)$ & $160,083(48)$ & $7706(2)$ & $10,232(3)$ & $334,841(100)$ \\
WELL & $2,345,149(73)$ & $768,353(24)$ & $37,871(1)$ & $52,145(2)$ & $3,203,518(100)$ \\
\hline
\end{tabular}




\section{References}

1. Jo, D.; Park, H.Y.; Choe, Y.; Kim, D.K. Destination-selection attributes for international association meetings: A mixed-methods study. J. Dest. Mark. Manag. 2019, 13, 61-72. [CrossRef]

2. Sung, H.; Lee, W. The effect of basic, performance and excitement service factors of a convention center on attendees' experiential value and satisfaction: A case study of the Phoenix Convention Center. J. Conv. Event Tour. 2015, 16, 175-199. [CrossRef]

3. Becattini, G. Industrial sectors and industrial districts: Tools for industrial analysis. Eur. Plan. Stud. 2002, 10, 483-493. [CrossRef]

4. Parrish, E.D.; Cassil, N.L.; Oxenham, W. Niche market strategy for a mature marketplace. Mark. Intell. Plan. 2006, 24, 694-707. [CrossRef]

5. Della Corte, V.; Aria, M. Coopetition and sustainable competitive advantage: The case of tourist destinations. Tour. Manag. 2016, 54, 524-540. [CrossRef]

6. Govers, R.; Go, F.M. Deconstructing destination image in the information age. Inf. Technol. Tour. 2003, 6, 13-29. [CrossRef]

7. Zhou, Y.; Maumbe, K.; Deng, J.; Selin, S.W. Resource-based destination competitiveness evaluation using a hybrid analytic hierarchy process (AHP): The case study of West Virginia. Tour. Manag. 2015, 15, 72-80. [CrossRef]

8. Gomezelj, D.O.; Mihalič, T. Destination competitiveness: Applying different models, the case of Slovenia. Tour. Manag. 2008, 29, 294-307. [CrossRef]

9. Crouch, G.I.; Del Chiappa, G.; Perdue, R.R. International convention tourism: A choice modelling experiment of host city competition. Tour. Manag. 2019, 71, 530-542. [CrossRef]

10. Cro, S.; Martins, A.M. International association meetings: Importance of destination attributes. J. Vacat. Mark. 2018, 24, 218-233. [CrossRef]

11. Dioko, L.; Whitfield, J. Price competitiveness and government incentives for simulating the meetings industry: A critical look at the case of Macau. Int. J. Event Festiv. Manag. 2015, 6, 39-53. [CrossRef]

12. Lee, T.J. The successful conference venue: Perceptions of conference organizers and hotel managers. Event Manag. 2009, 13, 171-180. [CrossRef]

13. McCartney, G. The CAT (Casino Tourism) and the MICE (Meetings, Incentives, Conventions, Exhibitions): Key development considerations for the convention and exhibition industry in Macao. J. Conv. Event Tour. 2008, 9, 293-308. [CrossRef]

14. Park, J.; Wu, B.; Shen, Y. The great halls of China? Meeting planners' perceptions of Beijing as an international convention destination. J. Conv. Event Tour. 2014, 15, 244-270. [CrossRef]

15. Tanford, S.; Montgomery, R.; Nelson, K. Factors that influence attendance, satisfaction, and loyalty for conventions. J. Conv. Event Tour. 2012, 13, 290-318. [CrossRef]

16. Hahm, J.J.; Tasci, A.D.A.; Terry, D.B. The Olympic Games' impact on South Korea's image. J. Dest. Mark. Manag. 2019, 14, 100373. [CrossRef]

17. Mahadewi, N.M.E.; Bendesa, K.G.; Antara, I.M. Interrelation multi-factors of MICE destination to tourist revisit. Int. J. Adv. Sci. 2019, 129, 99-110. [CrossRef]

18. Van Niekerk, M. Contemporary issues in events, festivals and destination management. Int. J. Contemp. Hosp. Manag. 2017, 29, 842-847. [CrossRef]

19. Brass, D.J.; Galaskiewicz, J.; Greve, H.R.; Tsai, W. Taking stock of networks and organizations: A multilevel perspective. Acad. Manag. J. 2004, 47, 795-817. [CrossRef]

20. Zemla, M. Inter-destination cooperation: Forms, facilitator and inhibitors-The case of Poland. J. Dest. Mark. Manag. 2014, 3 , 241-252. [CrossRef]

21. Lee, J.; Choi, Y.; Breiter, D. An exploratory study of convention destination competitiveness from attendees' perspective: IPA \& repeated measures of MANOVA. J. Hosp. Tour. Res. 2016, 40, 589-610. [CrossRef]

22. Ordanini, A.; Pasini, P. Service co-production and value co-creation: The case for a service-oriented architecture (SOA). Eur. Manag. J. 2008, 26, 289-297. [CrossRef]

23. Kylanen, M.; Mariani, M.M. Unpacking the temporal dimension of coopetition in tourism destinations: Evidence from Finnish and Italian theme parks. Int. J. Tour. Hosp. Res. 2012, 23, 61-74. [CrossRef]

24. Luo, Y. Coopetition in international business. Int. Bus. Rev. 2006, 15, 436-438. [CrossRef]

25. Wang, Y.; Krakover, S. Destination marketing: Competition, cooperation or coopetition. Int. J. Contemp. Hosp. Manag. 2008, 20, 126-141. [CrossRef]

26. Von Friedrichs Grangsjo, Y. Destination networking Co-opetition in peripheral surroundings. Int. J. Phys. Distrib. 2003, 33, 427-448. [CrossRef]

27. Rusko, R.; Merenheimo, P.; Haanpaa, M. Coopetition, resource-based view and legend: Cases of Christmas tourism and city of Rovaniemi. Int. J. Mark. Stud. 2013, 5, 37-51. [CrossRef]

28. Gnyawali, D.R.; Park, B.J.R. Coopetition and technological innovation in small and medium sized enterprises: A multilevel conceptual model. J. Small Bus. Manag. 2009, 47, 308-330. [CrossRef]

29. Kim, H.J.; Chen, M.H. Tourism expansion and economic development: The case of Taiwan. Tour. Manag. 2006, 27, 925-933. [CrossRef] [PubMed]

30. Hong, W.C. Competitiveness in the Tourism Sector: A Comprehensive Approach from Economic and Management Points; Physica-Verlag: Heidelberg, Germany, 2008; pp. 19-20. 
31. Harrison, B.; Foley, C.; Edwards, D.; Donaghy, G. Outcomes and challenges of an international convention center's local procurement strategy. Tour. Manag. 2019, 75, 328-339. [CrossRef]

32. Crouch, G.I.; Ritchie, J.B.R. Convention site selection research. J. Convent. Exhibit. Manag. 1997, 1, 49-69. [CrossRef]

33. Go, F.M.; Govers, R. The Asian perspective: Which international conference destinations in Asia are the most competitive? J. Convent. Exhibit. Manag. 1999, 1, 37-50. [CrossRef]

34. Getz, D. Bidding on events: Critical success factors. J. Convent. Exhibit. Manag. 2004, 5, 1-24. [CrossRef]

35. Yoo, J.J.E.; Chon, K. Factors affecting convention participation decision-making: Developing a measurement scale. J. Travel Res. 2008, 47, 113-122. [CrossRef]

36. Qu, H.; Li, L.; Chu, G.K.T. The comparative analysis of Hong Kong as an international conference destination in Southeast Asia. Tour. Manag. 2000, 21, 643-648. [CrossRef]

37. Wan, Y.K.P. Assessing the strengths and weaknesses of Macao as an attractive meeting and convention destination: Perspectives of key informants. J. Conv. Event Tour. 2011, 12, 129-151. [CrossRef]

38. Sangpikul, A.; Kim, S. An overview and identification of barriers affecting the meeting and convention industry in Thailand. J. Conv. Event Tour. 2009, 10, 185-210. [CrossRef]

39. Yoo, J.J.E. Development of the convention industry in Korea. J. Conv. Event Tour. 2004, 6, 81-94. [CrossRef]

40. Baloglu, S.; Love, C. Association meeting planners' perceptions and intentions for five major US convention cities: The structured and unstructured images. Tour. Manag. 2005, 26, 743-752. [CrossRef]

41. Nadkarni, S.; Leong, A.M.W. Macao's MICE dreams: Opportunities and challenges. Int. J. Event Manag. Res. $2007,3,47-57$.

42. Akerman, A.; Py, L. Service Outsourcing and Specialization: A Theory on Endogenous Task Scope; Stockholm University: Stockholm, Sweden, 2010.

43. Dimmick, J.; Kline, S.; Stafford, L. The gratification niches of personal e-mail and the telephone: Competition, displacement, and complementarity. Commun. Res. 2000, 27, 227-248. [CrossRef]

44. Min, S.J.; Kim, Y.M. Choosing the right media for mobilization: Issue advocacy groups' media niches in the competitive media environment. Mass. Commun. Soc. 2012, 15, 225-244. [CrossRef]

45. Gan, C.; Wang, W. Uses and gratifications of social media: A comparison of microblog and WeChat. J. Inf. Technol. 2015, 17, 351-363. [CrossRef]

46. Dimmick, J.W.; Patterson, S.J.; Albarran, A.B. Competition between the cable and broadcast industries: A niche analysis. J. Media Econ. 1992, 5, 13-30. [CrossRef]

47. Nelson, R.R.; Winter, S.G. An Evolutionary Theory of Economic Change; Harvard University Press: Cambridge, MA, USA, 1982; pp. 348-351.

48. McPherson, M. An ecology of affiliation. Am. Sociol. Rev. 1983, 48, 519-532. [CrossRef]

49. Kim, C.; Park, H.S. Competition or coexistence? Public relations industry in Korea: An application of the theory of the niche. Korea. J. Public Relat. 2006, 10, 126-160.

50. Dimmick, J. Media Competition and Coexistence: The Theory of the Niche, 1st ed.; Lawrence Erlbaum: Mahwah, NJ, USA, 2003; pp. 118-129.

51. Dimmick, J.; Feaster, J.C.; Ramirez, A., Jr. The niche of interpersonal media: Relationships in time and space. New Media Soc. 2011, 13, 1265-1282. [CrossRef]

52. Haniff, Z. Niche Theory in New Media: Is Digital Overtaking the Print Magazine Industry? Master's Thesis, University of Nevada, Las Vegas, NV, USA, 1 May 2012.

53. Ramirez, A., Jr.; Dimmick, J.; Feaster, J.; Lin, S.F. Revisiting interpersonal media competition: The gratification niches of instant messaging, e-mail, and the telephone. Commun. Res. 2008, 35, 529-547. [CrossRef]

54. Pasquinelli, C. Compeition, cooperation and co-opetition: Unfolding the process of inter-territorial branding. Urban Res. Pract. 2013, 6, 1-18. [CrossRef]

55. Ford, R.C.; Peeper, W.C. Managing Destination Marketing Organization; ForPer Publications: Orlando, FL, USA, 2008 ; p. 548.

56. Bengtsson, M.; Kock, S. “Coopetition” in business networks: To cooperate and compete simultaneously. Ind. Mark. Manag. 2000, 29, 411-426. [CrossRef]

57. Bouncken, R.B.; Gast, J.; Kraus, S.; Bogers, M. Coopetition: A systematic review, synthesis, and future research directions. Rev. Manag. Sci. 2015, 9, 577-601. [CrossRef]

58. Bengtsson, M.; Raza-Ullah, T.; Vanyushyn, V. The coopetition paradox and tension: The moderating role of coopetition capability. Ind. Mark. Manag. 2016, 53, 19-30. [CrossRef]

59. Ritala, P.; Hurmelinna-Laukkanen, P. What's in it for me? Creating and appropriating value in innovation-related coopetition. Technovation 2009, 29, 819-828. [CrossRef]

60. Bengtsson, M.; Kock, S. Coopetition-Quo vadis? Past accomplishments and future challenges. Ind. Mark. Manag. 2014, 43, 180-188. [CrossRef]

61. Dimmick, J.; Chen, Y.; Li, Z. Competition between the internet and traditional news media: The gratification-opportunities niche dimension. J. Media Econ. 2004, 17, 19-33. [CrossRef] 
62. Cho, Y.; Lee, Y. Technology Strategy under Industrial Environment of 'Coopetition': Patent Analysis in Mobile Industry; Korean Institute of Intellectual Property: Seoul, Korea, 2014.

63. Getz, D.; Andersson, T. Analyzing whole populations of festivals and events: An application of organizational ecology. J. Policy Res. Tour. Leis. Events 2016, 8, 249-273. [CrossRef] 